University of Arkansas, Fayetteville

ScholarWorks@UARK

$5-29-2015$

\title{
Collective Bargaining and District Costs for Teacher Health Insurance: An Examination of the Data from the BLS and Wisconsin
}

Robert M. Costrell

University of Arkansas, Fayetteville, costrell@uark.edu

Follow this and additional works at: https://scholarworks.uark.edu/edrepub

Part of the Educational Assessment, Evaluation, and Research Commons, Educational Leadership Commons, and the Other Educational Administration and Supervision Commons

\section{Citation}

Costrell, R. M. (2015). Collective Bargaining and District Costs for Teacher Health Insurance: An Examination of the Data from the BLS and Wisconsin. Education Reform Faculty and Graduate Students Publications. Retrieved from https://scholarworks.uark.edu/edrepub/114

This Article is brought to you for free and open access by the Education Reform at ScholarWorks@UARK. It has been accepted for inclusion in Education Reform Faculty and Graduate Students Publications by an authorized administrator of ScholarWorks@UARK. For more information, please contact scholar@uark.edu. 


\title{
Collective Bargaining and District Costs for Teacher Health Insurance:
}

\section{An Examination of the Data from the BLS and Wisconsin}

Robert M. Costrell ${ }^{*}$

Department of Education Reform

University of Arkansas

Fayetteville, AR 72701

costrell@uark.edu

May 29, 2015; revised June 23, 2015

Forthcoming, Journal of School Choice 9(4) (2015, in press)

doi: 10.1080/15582159.2015.1079471

\begin{abstract}
$\underline{\text { Abstract }}$
District costs for teachers' health insurance are, on average, higher than employer costs for private-sector professionals. How much of this is attributable to collective bargaining? This paper examines the question using data from the National Compensation Survey (NCS) of the Bureau of Labor Statistics (BLS) and the state of Wisconsin. In addition, the impact of collective bargaining on employer costs is decomposed into the impact on total premiums and the employer's share of those premiums.

The BLS data show that unionization is associated with higher total premiums, higher employer costs, and lower employee contributions in both the public and private sectors. This suggests that the high unionization rate among teachers plays a significant role in districts' higher average cost. Varying strength of teachers unions across states also helps explain the wide variation in district costs. In states with strong unions, such as Wisconsin, prior to 2011, district insurance costs can be very expensive. It is in those states that the opportunities for district cost reduction are most promising. I examine newly available data from Wisconsin to quantify the impact of that state's 2011 change in collective bargaining law, Act 10. I find a sharp reduction in district costs from lower-cost policies and higher teacher contributions: 13 to 19 percent in the first year after Act 10, and 18 to 23 percent after the second year, relative to projected district costs.
\end{abstract}

Keywords: teacher health insurance, collective bargaining

\footnotetext{
* I would like to acknowledge the support of the George W. Bush Institute, the research assistance of Jeffery Dean for an early version of this paper, and also the Bureau of Labor Statistics for providing unpublished data. Costrell (2015) provides more complete annotation and details on some of the calculations below.
} 


\section{$\underline{\text { Introduction and Summary }}$}

Rising costs for employer-provided health insurance have long been a matter of national concern, both in general and specifically for K-12 education. School budgets have been hit by these costs, and the fiscal strain of recent years has brought this into greater focus, with special attention to the role of collective bargaining. The high-profile battle in 2011 over Wisconsin's collective bargaining on public-sector benefits (Act 10), as well as lower-profile battles in Ohio and Massachusetts, was, to a great extent, about district health insurance costs for teachers (Costrell, 2011a, 2011b). This paper examines the question of collective bargaining's impact on employer costs for teachers' health insurance.

By way of background, data from the Bureau of Labor Statistics (BLS) show that the employer cost for teachers' insurance rose at an annual rate of 7.2 percent from March 2004 (the first year such data are available) to March 2011, while the Consumer Price Index (CPI) grew at 2.5 percent. Since then, insurance costs have notably slowed, bringing the 11-year average (through March 2015) down to 5.1 percent, compared to 2.1 percent for the CPI.

I estimate that districts currently spend about $\$ 543$ per pupil annually on teacher's insurance (this does not include teacher contributions). This national average covers a wide range, from states with relatively low employer costs to states with high ones. Among the latter, I estimate that Wisconsin districts averaged between $\$ 810$ and $\$ 977$ per pupil in 2011 , prior to the reduction in employer costs that followed that state's change in collective bargaining law. These figures do not include district insurance costs for other school employees or retiree health care, which tend to move in tandem with teachers' insurance. Neither of these costs is considered in this paper, but they can be quite substantial. For Milwaukee Public Schools employee health insurance (teachers and non-teachers) cost the district \$2,610 per pupil in 2011. 
Adding in retiree health insurance brought the total to $\$ 3,441$ (Milwaukee Public Schools, 2010) While these figures are not representative of the nation as a whole, neither is Milwaukee an isolated example: many districts in various states have struggled with high health care costs.

In this paper, I first examine data from the National Compensation Survey (NCS) of the BLS to compare employer costs for K-12 teacher health insurance with employer costs for private-sector professionals. Since the former sector is much more highly unionized than the latter, the gap I find between their employer costs provides a prima facie rationale for examining the data further, by union status. Such BLS data are not available at the occupational level, but for the public (state and local) and private sectors as a whole, unionization is associated with higher total premiums, higher employer costs, and lower employee contributions. This suggests the high unionization rate among teachers plays a significant role in districts' higher average cost.

To be sure, this association falls well short of methodological standards for causality. However, it may be considered to complement another study of national data that finds a strong effect of teachers' unionization on benefit costs (Clemens and Cutler, 2014). That study rests on a more causal methodology, but relies on data from the National Center for Education Statistics (NCES) that does not separate health benefits from pension benefits. Since health benefits are often subject to local collective bargaining while pension benefits are, instead, determined legislatively, the authors rightly caution the reader on the inference between teachers' unionization and health insurance costs.

As an alternative to cross-sectional analysis, the state of Wisconsin offers a striking opportunity for intertemporal comparison, due to that state's dramatic 2011 policy change that removed health benefits from local collective bargaining. I find a sharp reduction in district 
costs (from lower-cost policies and higher teacher contributions): 13 to 19 percent, in the first year after Act 10, and 18 to 23 percent after the second year, relative to projected district costs.

\section{Employer Health Care Costs: Teachers vs. Private-Sector Professionals - Nationally}

I begin with a basic, top-level question: how do employer health care costs for teachers compare with those for private-sector professionals? The most comprehensive national data published on employer costs is the Bureau of Labor Statistics' (BLS) National Compensation Survey (NCS) quarterly estimates of Employer Costs for Employee Compensation (ECEC). This series provides estimates of wages and benefits on a "per hour worked" basis, which is not conceptually ideal, but with the help of unpublished BLS data on annual hours worked, one can arrive at useful estimates of annual benefit costs. Notably, although there are heated debates regarding measurements of annual vs. hourly compensation for teachers, those debates are irrelevant to the calculations here, as explained in Costrell (2015). The conclusion I reach is that annual employer health care costs for teachers are significantly higher -17 to 23 percent - than those for private-sector professionals (controlling for the mix of part-time and full-time), as of March 2015. Although this gap is wider than it was in March 2004 (the first year that K-12 teacher breakout data were available), it has narrowed from its peak in March 2011, of 30 to 36 percent (I focus here on March estimates, since those are the most comparable, year-to-year). Figure 1 presents my quarterly estimates of annual employer insurance costs from 2004 to 2015 for state and local public K-12 teachers and private sector professionals. It shows the gap between the two sectors widening and then narrowing, but remaining substantial: $\$ 8,845$ vs. $\$ 7,540$, or 17 percent for March 2015. (The 23 percent figure given above -- along with the corresponding figure of 36 percent for March 2011 -- reflects an adjustment for the small 
component of non-health insurance in the "insurance" data, and how that component differs between the two sectors.)

\section{[INSERT FIGURE 1 APPROXIMATELY HERE]}

These estimates for employer insurance costs are averages over those employees who are covered by an employer's plan and those who are not. Employees may not be covered either because no plan is offered or because the employee chooses not to participate (e.g., due to coverage by the employer of one's spouse). The NCS Employee Benefits Survey (EBS) provides annual estimates of coverage rates for health care benefits that illustrate these points.

Almost all K-12 teachers (98 percent) have access to employer-provided health insurance. However, the Take-up Rate is only 88 percent, so the Participation Rate (the product of the Access and Take-up Rates) is 86 percent. The Participation Rate for private-sector professionals is only 69 percent, due to both lower Access and Take-up Rates, but these also reflect the higher rate of part-time employment in that group. Adjusting for the part-timers (i.e. simulating a sectoral average with the same full-time rate as K-12 teachers), I estimate a participation rate for private-sector professionals of 78 percent, vs. 86 percent for K-12 teachers.

Since non-participating employees incur no cost for employers, I can divide the average employer cost above by the participation rate to estimate the employer cost for participating employees, a calculation suggested by the BLS (Ford, 2009). Thus, for K-12 teachers, dividing the average annual employer cost of $\$ 8,845$ by their 86 percent participation rate yields a cost of $\$ 10,285$ for participating teachers in March 2015. For private-sector professionals, the corresponding estimate is $\$ 7,540 / 0.78=\$ 9,677$ employer cost for participating employees. This is 94 percent of that for teachers. Equivalently, the annual employer health insurance cost for participating teachers is 6 to 11 percent higher than for private-sector professionals. As we saw 
above, before factoring out non-participants, the estimate was 17 to 23 percent. Thus the difference in participation rates accounts half or more of the gap in employer costs between the two sectors.

\section{Employer Costs for Medical Insurance Premiums - Nationally}

The EBS also collects data each March on premiums for employer-provided medical care benefits. These data differ from the ECEC data discussed above in a few significant ways. First, "medical care" is narrower than "health care", although it is the most expensive component. The health insurance costs analyzed above include dental, vision, and outpatient drugs, as well as "medical care," the sole subject of this section. Another difference is that the EBS data are from direct examination of plan premiums, unlike the ECEC data discussed above, based on employer expenditures. One advantage is that the medical premiums are broken out by single and family coverage, so these data allow us to compare the cost of comparable policies. One disadvantage is that a composite average is not reported. Another disadvantage, as the BLS $(2009$, p. 20) states, is that "[t]he calculations [of employer and employee medical premiums] are based, not on actual decisions regarding medical coverage made by employees within the occupations, but rather on the assumption that all employees in the occupation have identical coverage." Thus, these data, on covered workers, do not reflect differences in participation rates.

Figure 2 depicts the employer premiums (converted from monthly to annual dollar amounts), for single and family coverage, from March 2008 to March 2014 (the most recent available at the time of this writing). Employer costs for single coverage of private-sector professional employees are now 84 percent of those for teachers, but for family coverage, they are 105 percent - slightly higher. This is a notable shift in the last few years, up from 74 percent 
and 100 percent, respectively, since 2008. As recently as 2009 , the employer premium for single coverage was $\$ 1,361$ higher for teachers than for private-sector professionals, compared to $\$ 936$ today and for family coverage it was $\$ 29$ higher instead of $\$ 517$ lower. This suggests that under prolonged fiscal duress some districts have begun to adjust their policies toward private sector norms. Although not directly comparable with my estimates of insurance costs in Figure 1, there, too, I found some narrowing of the gap over the last few years, as mentioned above.

\section{[INSERT FIGURE 2 APPROXIMATELY HERE]}

Neither set of NCS data - those presented in Figure 1 or 2 - provides the full picture comparing employer costs for teachers and private-sector professionals, but together they add to our understanding. The data in Figure 1 were based on the ECEC data, collected specifically to measure employer costs. They do not tell us how much of the gap between teachers and privatesector professionals is due to a different mix of family and single coverage (or, for that matter, in which direction the difference tilts). From the viewpoint of district finances, however, this may be irrelevant. Conversely, the EBS data on premiums offer useful detail not available in the ECEC data. These include data on employee premiums and total premiums, and, notably for the purposes of this paper, some breakout by union vs. non-union status, as discussed below.

The main take-aways thus far, however, are: (1) employer costs for K-12 teachers' insurance exceed those for private-sector professionals, although the gap has narrowed since 2011 (Figure 1); and (2) employer medical care premiums for K-12 teachers exceed those for private-sector professionals for single coverage, but no longer for family coverage (Figure 2). 


\section{Total Medical Premium and Employee/Employer Split - Nationally}

K-12 employer costs can be higher than for private professionals for two reasons: (i) higher-priced policies; and/or (ii) lower employee premiums. EBS data on the share of total premiums paid by the employer allow us to infer the total and the employee premiums.

Figure 3 depicts total medical premiums and the employer/employee split using March 2014 data from the EBS. The left panel depicts single coverage. Using the EBS estimate of the employer share of total premiums -87 percent for teachers, 81 percent for private-sector professionals - we infer that total premiums are $\$ 6,665$ for teachers and $\$ 6,003$ for private-sector professionals. (For example, using the teachers' share, 87 percent, and the EBS estimate of $\$ 5,798$ for their employers' premium, we calculate the total premium for teachers as $\$ 5,798 / 0.87$ $=\$ 6,665$.$) The difference, \$ 662$, accounts for over 70 percent of the $\$ 936$ difference in employer costs. The rest (\$274) represents the lower employee premiums.

\section{[INSERT FIGURE 3 APPROXIMATELY HERE]}

The right panel of Figure 3 depicts the premiums for family coverage. The employer share for teachers' family premiums is lower than for private-sector professionals, 66 percent vs. 71 percent. The total premium for teachers' policies is a bit higher $(\$ 490)$, but the employee contribution is higher yet $(\$ 1,007)$, so the employer cost is lower $(\$ 517)$. That is, family policies for teachers are more expensive than for private-sector professionals, but the teachers more than cover the difference.

For both single and family plans, total premiums have been higher for teachers than for private-sector professionals since at least 2008 (data not shown here). In addition, for single coverage, teachers have consistently paid less than private-sector professionals. For family 
coverage, teachers have paid more, covering or (since 2010) more than covering the higher cost of their policies.

There are many reasons that insurance plans can differ in total premiums, but some of the main ones are those provisions that govern out-of-pocket expenditures by the employee, over and above the employee premium. These features include deductibles, co-payments, co-insurance, and out-of-pocket maximums. The NCS publications on Health Plan Provisions provide some of these details, including deductibles and out-of-pocket maximums. Data through 2011 (the most recent available for K-12 teachers) generally show higher family and individual deductibles for private-sector professionals than K-12 teachers, although for other measures, such as out-ofpocket maximums, the pattern is more mixed. Overall, the data suggest that some portion of the higher total premiums for K-12 teachers is related to their lower out-of-pocket costs. This does not affect the comparisons of district cost, but it does mean that the comparison of employee premiums is not the full story on teacher costs. While it is accurate to state that teachers pay more to get more in the way of family coverage, it is more precise to state that they pay more up front in premiums and then pay less out-of-pocket. Whether they get more in the way of health services (higher quantity or quality) is impossible to tell from the available data.

\section{Union vs. Nonunion Medical Benefits in the Public and Private Sectors - Nationally}

The NCS EBS data allow us to compare medical insurance coverage and premiums for union vs. nonunion workers (defined by BLS as whether the employee belongs to a collective bargaining unit) in the public and private sectors. These breakouts are not available for K-12 teachers or private-sector professionals, but they are available for the state and local government sector and the private sector, each taken as a whole. Since teacher health care costs track the 
state and local sector to some extent (Costrell 2015), this level of aggregation can still be informative.

Table 1 shows the medical care Access, Take-up and Participation Rates for union and nonunion workers in the state and local sector and private industry. Union workers have almost universal access to employer-provided insurance in both sectors (94-95 percent), and their participation rate is about the same in both sectors (78-80 percent). Nonunion workers are less likely to participate in an employer-provided plan, in large part because their employer is less likely to offer one. The difference from union workers, however, is smaller in the state and local government sector, where the nonunion participation rate is 67 percent, compared to 47 percent in the private sector. Thus, in accounting for the overall higher coverage rate in the state and local sector vs. private industry, I find that this is associated with the higher unionization rate in the public sector, but also reflects that sector's higher coverage for nonunion workers.

\section{[INSERT TABLE 1 APPROXIMATELY HERE]}

I now turn to employer and employee premiums for union and nonunion employees in the two sectors. The data are presented in Figure 4, for single and family coverage. These data show that in each sector, for each type of coverage, the employer cost is higher for union workers. They also show that the total premium is higher for union workers. Finally, they show lower employee contributions for union workers, except for single coverage in the state and local sector.

\section{[INSERT FIGURE 4 APPROXIMATELY HERE]}

The state and local sector as a whole exhibits the same patterns in comparison to the private sector as the union sector does to the nonunion sector: higher employer costs, higher total premiums, and lower employee contributions, for both types of coverage (Costrell, 2015, 
Tables 5 and 6). In part, this reflects the higher unionization rate for the state and local sector: 50 percent vs. 13 percent in this dataset. Specifically, using a standard shift-share analysis, we can decompose the differences in premiums (total, employer, and employee) between the private and public sectors by controlling for unionization (i.e. assuming they are the same for both sectors) and attributing the rest of the difference to the difference in unionization rates. This exercise indicates that the higher public unionization rate plays a substantial role in each of these three patterns: higher total premiums, higher employer premiums, and lower employee premiums in the state and local sector, for both types of coverage.

As we have seen, however, these are not entirely the patterns observed between K-12 teachers and private-sector professionals: they hold for single coverage, but not family coverage. Clearly, whatever impact unionization may have, there are other confounding factors at play in explaining the national averages for teachers vs. private professionals.

There is one state, however, which provides an arguably natural experiment in changing teacher union strength: Wisconsin. If union strength results in higher employer costs, higher total premiums, and generally lower employee contributions (as illustrated in Figure 4), then the removal of teacher health benefits from collective bargaining in Wisconsin might be expected to have the opposite effect: reducing employer costs, reducing total premiums, and raising employee contributions. As I will show, this is exactly what happened.

\section{Wisconsin: Before and After Act 10}

Wisconsin was the first state in the nation with public sector collective bargaining (Moe, 2011, p. 36), and long had one of the nation's strongest teachers unions -- 99 percent unionization rate prior to Act 10 (Moe, 2011, p. 54). It had also long been a state with very expensive teacher 
medical insurance. As the data below will show, average district costs in 2011 were $\$ 8,059$ and $\$ 18,947$ for single and family coverage. These premiums are 47 percent and 77 percent higher than the 2011 national averages, $\$ 5,500$ and $\$ 10,723$. Wisconsin is in a region with higher than average costs (East North Central), but the NCS data on employer premiums for state and local employees in 2011 indicate that the geographic factor only raised single coverage rates by 10 percent above the national average and family coverage by 29 percent. Other factors have played a greater role in Wisconsin's high district costs for teachers' insurance, and the state's collective bargaining environment was an important contributor.

Prior to Act 10, Wisconsin's highly contested 2011 measure that restricted public sector collective bargaining privileges, teachers' insurance was subject to local collective bargaining. An important feature of the districts' collective bargaining landscape was the WEA Trust, a vehicle to provide medical insurance to Wisconsin public schools that was created in 1970 by the Wisconsin Education Association Council (the state teachers' union, an affiliate of the National Education Association) and that is still closely associated with WEAC (Miller, et. al., 2005; the WEA Trust website; and Kertscher, 2012). Quite frequently, this meant that local collective bargaining agreements restricted districts to purchasing insurance from the WEA Trust, thereby limiting districts' ability to shop for lower-cost alternatives. This feature was long a matter of concern in Wisconsin and even prior to Act 10 there was significant movement away from WEA Trust plans, from almost 80 percent of the teachers' market in 2004 to about 60 percent in 2010 (D’Andrea, 2011a; see also Kertscher, 2012 and Education Action Group Foundation, 2010). However, such moves were often difficult. Even when collective bargaining agreements allowed districts to search for competitive bids, there were many documented cases where the WEA Trust failed to produce the claims data necessary for districts to provide to prospective 
competitors to prepare bids, and penalized districts that sought such information (Miller, et. al., 2005; Education Action Group Foundation, 2010). On the eve of Act 10, most districts still purchased their insurance from WEA Trust, even though these plans (and Wisconsin teacher plans more generally), were often more expensive than other plans (in addition to the reports cited above, see HC Trends, 2011).

In addition, teacher contributions to their medical premiums were generally low. In the last school year before Act 10 (2010-11) teachers made no contribution at all for single coverage in 43 percent of the state's districts, or for family coverage in 31 percent. These non-contributory rates, calculated from the WASB survey data discussed below, had gradually drifted downward from 59 percent and 44 percent, respectively, in 2002-03, but were still relatively high. By comparison, the 2011 non-contributory rates among teachers in the national data discussed above were 39 percent and 16 percent respectively. Among private-sector professional employees nationally the 2011 non-contributory rates for single and family plans were 17 percent and 9 percent. Factoring in contributory plans, for another measure, the average contribution rates among Wisconsin teachers were also quite low, as shown below.

In 2010, both candidates for governor (Republican Scott Walker and Democrat Tom Barrett), as well as the Wisconsin Association of School Boards (WASB), advocated measures to help localities move into less expensive plans without requiring agreement from local unions (although Barrett's plan exempted teachers). The state employees' plan received particular attention. State law already allowed localities to place employees in that plan, but under collective bargaining such moves required local union agreement (Miller, et. al., 2005). Thus, both parties, to differing degrees, supported changes to collective bargaining law covering benefits - a point that was lost in the subsequent turmoil. 
Act 10, proposed by Governor Walker and enacted by the Legislature in 2011, removed benefits from local collective bargaining, thereby giving districts greater freedom to shop for less expensive plans and negotiate premiums. This has resulted in a significant loss of business for WEA Trust and in negotiated reductions in premiums for business that it retained (Kertscher, 2012). The law also indirectly induced districts to establish higher employee contributions, by setting a maximum employer share for those districts that purchase insurance from the state's group insurance board ( 88 percent of the board's lowest cost plans in the service area.) This provision does not directly bind the vast majority of districts, which buy insurance from other entities (including WEA Trust), but it does seem to have established a benchmark that is being widely followed, of setting employee contributions in the vicinity of 12 percent. Prior to Act 10, teacher contributions were often zero (as discussed above) and were under 10 percent in the vast majority of districts: 84 percent for single coverage and 74 percent for family.

These changes were intended to achieve savings on district benefit costs, from adopting plans with lower premiums and increasing teacher contributions. Since the passage of Act 10, evidence has accumulated of individual districts saving money (D'Andrea, 2011b, Wisconsin Taxpayer Alliance, 2012), and, more recently, data have become available to evaluate savings statewide.

\section{Data on Medical Premiums in Wisconsin School Districts}

The Wisconsin Association of School Boards (WASB) published annual data on medical premiums paid by districts and teachers from 2002-03 to 2012-13. These data are reported for single and family coverage. The 2011-12 rates (hereafter, 2012) were the first to be affected by Act 10. However, they did not reflect the Act's total impact, because some districts had yet to 
renegotiate their insurance, as some were under insurance contracts predating Act 10 and some were bound by pre-Act 10 collective bargaining agreements that had not yet expired. Thus, I also examine the 2013 rates (WASB has not reported any subsequent data).

One weakness of the WASB data is that, in each year, a number of districts do not respond to the survey. While every district appears in at least one year (Wisconsin currently has 424 traditional public school districts), the number has varied from 277 to 426 in the WASB data, between 2003 and 2011. The data for 2012 and 2013 cover 186 and 180 districts.

Since variable rates of missing data may introduce bias into my estimates of annual changes in premiums, I construct a chained estimate of yearly changes using only districts that appear in consecutive years. This is analogous to estimates of house prices that link a sales price to the same house's price on its previous sale. In my case, each year's estimate of annual change is based on the set of districts that also appears in the prior year's data. Of the 186 districts reporting in 2012, 131 also reported in 2011; and of the 180 in 2013, 94 also appear in 2012.

Another database that I examine is from the Wisconsin Department of Public Instruction (DPI). DPI compiles individual compensation data, including fringe benefits. This data set has the advantage of completeness, covering virtually all districts. It has the additional advantage of going back more years. The disadvantage is that this data set does not break out health or medical benefits from the overall fringe benefit cost for teachers. However, using what is known about the impact of Act 10 on district pension costs, the change in trajectory of total fringe costs reaffirms my general findings on medical insurance costs from the WASB data. 


\section{Trends in Wisconsin School District Medical Insurance Premiums: WASB Data}

Figure 5 presents average district premiums (i.e. excluding teacher contributions) for medical insurance in Wisconsin, for single and family coverage. The main takeaway, which I will closely dissect, is the sharp drop in district costs following Act 10, after years of steady growth.

\section{[INSERT FIGURE 5 APPROXIMATELY HERE]}

Methodological Issues: Weighted vs. Unweighted and Chained vs. Raw Averages

Figure 5 presents weighted and unweighted averages across all reporting districts in any given year. The unweighted figures are a simple average of employer premiums across all districts, regardless of size - these figures replicate the estimates reported by WASB (converted from monthly to annual). The weighted averages reflect district size, using the number of teachers, as measured by data on Full-Time Equivalents (FTE's) from Wisconsin's Department of Public Instruction. Up through 2010 the differences between the weighted and unweighted averages were minor. In 2011, however, the weighted averages grew noticeably more slowly than the unweighted averages, particularly for family coverage: $\$ 220$ vs. $\$ 892$ (as can be calculated from the data in Figure 5). One reason is that a number of large districts that had previously reported their data to WASB stopped doing so in 2011, most notably Milwaukee (far and away the largest district in the state). Up until then, the larger districts had generally included both high-cost and low-cost plans, as indicated by how close the two curves had been. Milwaukee, however, was among the highest-cost districts in the state in 2010, so its absence from the data in 2011 had a detectable negative impact on the weighted average, slowing its rate of growth. This example illustrates the general point that although weighted averages are usually 
more informative for examining cost levels, the changes in weighted averages can be more sensitive to missing data that vary by year.

The weakness in the estimates of annual change from these averages is that the districts compared in any pair of years will generally not match. The chained estimates are constructed to avoid this problem. For example, my chained estimates for the 2010-11 change are based on the 265 districts for which I have data on both years, whereas my averages of the raw data for 2010 and 2011 are drawn from 390 and 277 districts, respectively. The weighted and unweighted chained estimates for the 2010-11 change (\$629 and \$703, respectively, for family coverage) are much closer to each other than are the changes in the weighted and unweighted averages $(\$ 220$ and $\$ 892$ as discussed above). Thus, the chained methodology reduces spurious differences between weighted and unweighted estimates of growth.

That said, real differences do remain between weighted and unweighted estimates, even with chaining. For example, the weighted and unweighted chained estimates of the 2011-12 change in district cost of family coverage are $-\$ 2,036$ and $-\$ 2,821$, respectively, while the corresponding estimates from raw averages are $-\$ 2,166$ and $-\$ 2,769$. Thus, the difference between weighted and unweighted estimates for 2011-12 is not an artifact of the change in missing data. Rather, there appear to have been systematically larger reductions in employer premiums in the small districts than the large ones immediately after Act 10, at least in those 131 districts that were common to both the 2011 and 2012 datasets. For 2012-13, the weighted and unweighted chained estimates of change once again converge; however, there are only 94 districts common to those last two years.

The complete set of chained estimates is used to construct Figure 6. What is relevant in this figure is the year-to-year change in each curve, more so than the level. The level of the 
curves is fixed by choosing a base year, to which the chained estimates of annual change are applied. The base year chosen for Figure 6 is 2010, a year in which a very complete set of districts (390) reported to WASB, so the weighted and unweighted averages for that year (also depicted in Figure 5) are likely quite accurate. In my judgment, the estimated changes depicted in Figure 6 are generally more reliable than those depicted in Figure 5.

\section{[INSERT FIGURE 6 APPROXIMATELY HERE]}

\section{Results: Impact of Act 10}

The magnitude of the 2012 drop in district premiums is striking. As we have seen, for family coverage, chained district premiums fell an estimated $\$ 2,821$ (unweighted) and $\$ 2,036$ (weighted), and for single coverage, district premiums fell $\$ 1,396$ (unweighted) and $\$ 1,056$ (weighted). These are underestimates of district savings attributable to Act 10, since premiums were steadily rising prior to Act 10 and were expected to continue doing so. To be sure, the rise had slowed since 2007, so in extrapolating trends from 2011 to 2012, I use the average growth from 2007 to 2011. I estimate the district cost reduction in 2012, relative to trend, for family coverage to be $\$ 3,506$ (unweighted) and $\$ 2,639$ (weighted), while for single coverage the figures are $\$ 1,689$ (unweighted) and $\$ 1,318$ (weighted). These estimates, dissected further below, represent savings of 13-19 percent from the projected district premiums for 2012.

As Figure 6 shows, the decline in district premiums slowed or leveled off in 2013. However, given the likely continued growth in district premiums absent Act 10, it does appear that there were further district savings from Act 10. This would be consistent with the fact that more collective bargaining agreements expired, freeing up districts to obtain medical insurance in a less constrained environment. Specifically, Figure 6 shows a $\$ 397$ further reduction in district premiums for family coverage (weighted), on top of the $\$ 2,036$ in 2012 , for a two-year 
drop of $\$ 2,433$. Compared to two years of projected growth at the previous rate, I estimate the impact of Act 10 on district premiums for family coverage as $\$ 3,640$. This represents an 18 percent saving from the projected 2013 premium, under the pre-Act 10 trend. The other estimates range up to a 23 percent saving (single coverage, unweighted).

To be sure, these two-year estimates (18-23 percent savings) have more uncertainty than the one-year estimates (13-19 percent). First, as mentioned above, the chained estimates for 2012-13 are based on a smaller number of districts (94 vs. 131). Second, the counterfactual projected growth, based on 2007-11, is necessarily more conjectural for the second out-year than the first. That said, it does seem clear that additional savings did accrue in year two, and the estimate of 4-5 percent for those additional savings does not seem unreasonable.

\section{Decomposition of Wisconsin School District Savings}

Districts saved on their premiums for teacher medical insurance in 2012 and 2013 for two reasons: reductions in total premiums and increases in the share paid by teachers. As discussed above, Act 10 did not directly raise teachers' contributions, but the 12 percent standard it set for state employees and districts participating in the state plan provides an example for other districts (the vast majority) to follow, with the end of collective bargaining over benefits. Figure 7 illustrates the general pattern of teacher contributions. Between 2003 and 2011, average contributions hovered in the 3-4 percent range for single coverage and 4-5 percent for family coverage. In 2012, following Act 10, average contributions jumped to over 10 percent for both types of coverage, and to about 11 percent in 2013. This now places Wisconsin in the vicinity of the national average for contributions by teachers with single coverage (13 percent), but still far below the average for family coverage (34 percent). 


\section{[INSERT FIGURE 7 APPROXIMATELY HERE]}

In dollar terms, teacher contributions for family coverage rose by $\$ 990$ in 2012 and $\$ 77$ in 2013 , for a two-year rise of $\$ 1,067$, or $\$ 971$ relative to prior trends. At the same time, total premiums declined by $\$ 1,366$ (\$1,046 in 2012 and $\$ 320$ in 2013), or $\$ 2,669$ relative to trend, as districts have been able to shop for less expensive plans. Together, these comprise the $\$ 3,640$ district savings from Act 10 cited above for family coverage.

Figures 8 and 9 graphically depict the total premium, district premium, and the difference between the two, paid by the teachers, using unweighted and weighted chained estimates. The story these figures show is that after Act 10, total premiums went down and teacher contributions went up, both contributing to the decline in district costs for single and family coverage. This is exactly the pattern observed in the BLS data comparing union and nonunion workers on total premiums, employee contributions and employer costs, in the private and public sectors.

\section{[INSERT FIGURE 8 APPROXIMATELY HERE]}

\section{[INSERT FIGURE 9 APPROXIMATELY HERE]}

Table 2 brings together my detailed estimates of the impact of Wisconsin's Act 10 on district costs. Consider the weighted chained estimates for family coverage, tabulated in the last column. Row (1) gives the 2011-13 decline in total premiums, $\$ 1,366$ (depicted by the top curve in Figure 9). Row (2) gives the 2011-13 rise in teacher contributions, \$1,067 (the widening gap between the top two curves in Figure 9). Taking these together, row (3) shows the $\$ 2,433$ drop in district premiums by 2013 (depicted by the 2nd curve in Figure 9). Row (4) gives the trend growth in total premiums, $\$ 652$ per year (the average growth in the top curve of Figure 9 , from the kink point at 2007 to 2011), of which growing teacher contributions accounted for $\$ 48$ (row (5)). Thus, the trend growth in district premiums was $\$ 603$ (row (6)). Row (7) gives my 
estimate of Act 10's total impact on annual district premiums after two years: $\$ 3,640$; it is the 2011-13 decline of $\$ 2,433$ minus two times the annual trend growth of $\$ 603$. This can be decomposed into the impact on total premiums (row (8)) and on teacher contributions (row (9)). These comprise about three-fourths and one-fourth, respectively, of Act 10's total impact on district premiums (rows (10) and (11)). Finally, row (12) reports the estimated impact of Act 10 on district premiums as a percent of the projected 2013 premium, ranging from 18 percent to 23 percent, depending on coverage and weighting.

\section{[INSERT TABLE 2 APPROXIMATELY HERE]}

Two caveats are worth reiterating. First, these data on employee costs only measure employee premiums; they do not measure the level or changes in employee payments out-ofpocket for medical coverage (co-payments, deductibles, and coinsurance). It is certainly the case that some (maybe most) of the reduction in total premiums is due to a rise in employee out-ofpocket payments (referred to as "cost-sharing" in the industry). For example, there is some evidence of districts shifting toward higher deductibles (Breunlin, 2012). This does not affect my estimates of the impact on district cost, but it does mean that some portion of what is counted here as impact on "total premiums" actually represents the impact on employee out-of-pocket costs. That is, the share of district cost reduction due to higher employee costs (premiums plus out-of-pocket) is underestimated because the data are restricted to premiums.

Second, as previously discussed, these data do not tell us anything about the quantity and quality of medical care provided. There is some theoretical reason to believe that efficiency may be enhanced as employees (consumers of medical care) pay more of the cost and as employers become free to shop around. But I have no hard data on this. 


\section{District Cost of Fringe Benefits in Wisconsin}

As a check on the WASB data, I examined data from the Wisconsin Department of $\underline{\text { Public Instruction }}$ (DPI) on districts' fringe benefit costs for teachers. These data, unlike the WASB data, have no problem with missing districts. However, the DPI's publicly available dataset for teachers does not separate out health benefits from other fringe benefits, including retirement contributions, Social Security, and life insurance. The impact of Act 10 captured by these data will therefore include not only the impact on health insurance, but also the shift of about one-half of retirement contributions from employer to employee, mandated by the Act.

Figure 10 depicts the district fringe benefit costs for teachers in Wisconsin, from 1998 to 2013. The steady rise in dollar terms from 1998 to 2011 is also reflected in the remarkable rise of the fringe benefit rate (i.e. percent of salary), from 34.2 percent (referring here to the weighted averages) to 51.3 percent. After Act 10, the average fringe rate dropped 8.5 percentage points to 42.8 percent - still high by comparison with the private sector, but markedly reduced.

\section{[INSERT FIGURE 10 APPROXIMATELY HERE]}

Much of that drop reflects the shift in retirement contributions. Act 10 barred employers from picking up the employee share of contributions to the Wisconsin Retirement System (as had previously been the practice for nearly all school districts). That share was 5.8 percent of payroll in calendar year 2012 and 6.65 percent in 2013. This probably did not translate into a full 5.8 point drop in the fringe rate in the first year of Act 10, because some districts' pickup continued through 2012 and into 2013 due to unexpired contracts. That said, it seems likely that by 2013 about two-thirds of the 8.5 point drop in district fringe rates represents the shift in retirement contributions. 
Virtually all of the remainder represents the 2011-13 drop in district health benefit costs. Thus, of the total dollar drop in fringe benefit costs $(\$ 4,659$ weighted), these data suggest a drop of about $\$ 1,500$ in district health costs (weighted, and a bit more unweighted). These estimates are broadly consistent with my estimates based on the WASB data, presented in the top panel of Table 2 (i.e. ignoring trend), for plausible splits between single and family coverage.

\section{Looking Ahead in Wisconsin}

The WASB and DPI data show striking evidence of a large first-year impact of Act 10 on district costs for teacher health insurance, and further impact in year two. As time goes on, it will be more difficult to disentangle the effects of Act 10 from other developments in the increasingly turbulent health care market, but we do know that these developments will play out from a significantly lower starting point, due to Act 10 .

One important development to watch is the Federal tax on "Cadillac plans," slated for 2018 under the Affordable Care Act of 2010. This provision places a 40 percent excise tax on plans for which total premiums exceed $\$ 27,500$ (family) or $\$ 10,200$ (single). In 2011 , before Act 10, no district in the WASB database had yet exceeded the limit for family coverage, but 22 percent of the districts (with 11 percent of the state's teachers) had already exceeded the limit for single coverage. Projecting out from the pre-Act 10 level to 2018 at the prior trend rate, 78 percent of the districts (with 64 percent of the teachers) would exceed the single limit and 26 percent of districts (with 14 percent of the teachers) would exceed the family limit.

Even now, with the dramatic savings from Act 10, district costs and total premiums in Wisconsin are still well above the national average for teachers, and a handful of districts still exceed the Cadillac limit for single coverage. Projecting out to 2018, using the pre-2011 trend, 
a quarter of the districts (with one-sixth of the teachers) would exceed the limit for single coverage, and a handful would exceed it for family coverage. Thus, if and when the luxury tax is implemented, there will be continuing pressure to reduce plan costs in at least some of Wisconsin's districts, and Act 10 will make it easier for districts to avoid the Federal tax.

\section{Conclusion}

I have closely examined data from the BLS National Compensation Survey and the state of Wisconsin, to assess the impact of collective bargaining on district health insurance costs for teachers, both nationally and in the bellwether state that has repealed collective bargaining over benefits. Nationally, I found that annual employer insurance costs are 17-23 percent higher for teachers than for private-sector professionals, consistent with the K-12 sector's higher unionization rate. This gap has widened from 2004, but narrowed from its 2011 peak of 30-36 percent, suggesting that under prolonged fiscal duress some districts have begun to adjust their policies toward private sector norms.

Direct estimates of employer medical premiums present a mixed picture nationally: higher employer premiums for teachers with single coverage, but not family coverage. In both cases, total medical premiums are higher for teachers than for private-sector professionals, but for family coverage the teachers cover the extra premiums themselves. These data, too, show a shift since 2008 consistent with district cost-cutting under fiscal duress.

Even after this period of public fiscal strain, the NCS data show that unionization is still associated with higher total premiums, higher employer costs and lower employee contributions in both the public and private sectors. This suggests that the high unionization rate among teachers plays an important (if perhaps diminishing) role in districts' higher average cost. 
Equally important, varying strength of teachers unions across states helps explain the wide variation in district costs and employee contributions, variation that is masked by the averages. For example, NCS data on the distribution of employee premiums for family coverage (in contributory plans) show that teachers in the 90 th percentile contribute $\$ 13,061$ vs. $\$ 1,494$ at the 10th percentile. In some nonunion states, teacher health insurance benefits are not particularly generous, due to high out-of-pocket costs (e.g. high deductibles) or high teacher shares of premiums. In Arkansas (a state with only 17 percent collective bargaining, Moe, 2011, p. 55), until recently teachers typically paid 65 or 70 percent of the premiums for family coverage, and even now (2014) they pay 58 to 62 percent (the national average is 34 percent). In other states, with strong unions, district insurance costs can be very expensive. It is in those states that the opportunities for district cost reduction have been most promising - as our findings from Wisconsin so clearly show, with the repeal of collective bargaining for benefits reducing district medical insurance costs an estimated $18-23$ percent in two years. Some other states have also followed Wisconsin's lead (see, for example, Massachusetts Taxpayers Foundation, 2012) -- and opportunities may remain to be pursued in some other states.

The methods of district cost reduction would ideally include measures that enhance efficiency, such as greater competition for health insurance. Wisconsin's example comes to mind, where the WEA Trust's insulation from competition was weakened by Act 10. However, there should be no illusions that such efficiencies will come easily. In all likelihood, a great deal of any district cost reduction will take the form of higher teacher payments toward their health care through higher contributions and out-of-pocket expenses. This raises the question of the role of teacher health benefits in the total compensation package. The overall size of the total compensation package will continue to be the subject of debate, increasingly framed by the fiscal 
exigencies that districts now face. However, it is worth commenting on the structure of the package.

There are three reasons that efficiency might be enhanced by reallocating some of the compensation package from employer-paid health benefits to salary (a reallocation that has historically been discouraged by the favorable tax treatment of employer-provided insurance). First, as discussed briefly above (and quite extensively in the health care literature), efficiency in health care expenditures is more likely enhanced when the consumer is incentivized by some price signals (e.g. to participate in wellness programs). Second, there is significant bipartisan interest in various forms of differential pay. To the extent that compensation is shifted back to salary (in the aggregate), there is greater opportunity for districts to use salary differentials to retain, recruit, and selectively assign higher quality teachers. Finally, as a matter of consumer choice, not all employees may want their employers to devote, say, $\$ 20,000$ out of a $\$ 70,000$ compensation package to medical insurance. The fact that take-up rates are well under 100 percent is evidence that many teachers ascribe less value to the medical benefits offered than they cost, even with the employer paying the lion's share. Among these are teachers who decline insurance because they are covered by their spouse's plan, in which case the value of the benefit offered is zero, and a higher salary would clearly be preferable. Thus, both efficiency (in attracting recruits) and equity (toward non-participants) might be enhanced by such a shift. Ideally, employers could offer greater choice among medical plans of varying cost, with lower subsidies, fixed in size, and higher salaries that allow employees to choose how much they want to spend on higher-cost plans. As districts under fiscal distress increasingly turn to cost-cutting measures, such potential efficiency enhancements will become all the more important. 


\section{References}

Bureau of Labor Statistics. (2009) Handbook of Methods, Chapter 8, "National Compensation Measures".

Bureau of Labor Statistics. (2015a) National Compensation Survey, Employer Costs for Employee Compensation.

Bureau of Labor Statistics. (2015b) National Compensation Survey, Employer Benefits Survey.

Breunlin, E. (2012) "Teachers moving to pricier health plans," Milwaukee Journal Sentinel, April 21.

Clemens, J. and Cutler, David M. (2014). Who Pays for Public Employee Health Costs?

Journal of Health Economics, 38, 65-76.

Costrell, R. M. (2011a). Oh To Be a Teacher in Wisconsin. Wall Street Journal, February 25.

Costrell, R.M. (2011b) Collective Bargaining Weakens Cities. Wall Street Journal, November 23.

Costrell, R.M. (2015) District Costs for Teacher Health Insurance: An Examination of the Data from the BLS and Wisconsin. The George W. Bush Institute, Productivity for Results Series, No. 8 .

D'Andrea, C. (2011a) "Health Care Trends in Wisconsin's School Districts: A Look at the Expanding Market of Teacher Health Insurance," MacIver Institute.

D'Andrea, C. (2011b) "Wisconsin School Districts are Switching Health Care Providers/Plans to Create Savings in 2011," MacIver Institute.

Education Action Group Foundation (2010) "A crucial challenge for Wisconsin schools: Escaping the financial shackles of WEA Trust insurance."

Ford, J.L. (2009). "The New Health Participation and Access Data from the National Compensation Survey," U.S. Bureau of Labor Statistics.

HC Trends (2011). "How Teacher Health Plans Compare with Plans Offered by Milwaukee-Area Employers."

Kertscher, T. (2012) "Behind the rhetoric: The WEA Trust and School Health Care Costs," Politifact.

Massachusetts Taxpayers Foundation (2012) "One Year Later, Municipal Health Insurance Law a Smashing Success," July 11. 
Miller, J., et. al. (2005). "Health Insurance for Wisconsin Public Schools: The Case for Competitive Bidding," Wisconsin Policy Research Institute.

Milwaukee Public Schools (2010). "Superintendent’s Fiscal Year 2011 Proposed Budget."

Moe, T.M. (2011). Special Interest: Teachers Unions and America's Public Schools, Washington, D.C.: Brookings Institution Press.

Wisconsin Association of School Boards, "Teacher Health Insurance Cost and Contribution Comparisons."

Wisconsin Taxpayers Alliance, (2012). "After the Storm: School Funding in 2012," The Wisconsin Taxpayer. 
Table 1: Union and Nonunion Coverage Rates for Medical Care Benefits, March 2014

\begin{tabular}{|c|c|c|c|}
\hline & Access Rate & Take-up rate & $\begin{array}{l}\text { Participation } \\
\text { Rate }\end{array}$ \\
\hline \multicolumn{4}{|l|}{ UNION WORKERS } \\
\hline State and Local Government & $95 \%$ & $84 \%$ & $80 \%$ \\
\hline Private Industry & $94 \%$ & $83 \%$ & $78 \%$ \\
\hline \multicolumn{4}{|l|}{ NONUNION WORKERS } \\
\hline State and Local Government & $81 \%$ & $83 \%$ & $67 \%$ \\
\hline Private Industry & $67 \%$ & $71 \%$ & $47 \%$ \\
\hline \multicolumn{4}{|l|}{ ALL WORKERS } \\
\hline State and Local Government & $87 \%$ & $83 \%$ & $73 \%$ \\
\hline Private Industry & $69 \%$ & $72 \%$ & $50 \%$ \\
\hline
\end{tabular}

Source: BLS National Compensation Survey, Employee Benefits Survey. 
Table 2: Estimated Impact of Wisconsin's Act 10 on District Medical Premiums, 2011-2013

Chained estimates

\begin{tabular}{|c|c|c|c|c|}
\hline & \multicolumn{2}{|c|}{ unweighted } & \multicolumn{2}{|c|}{ weighted } \\
\hline & $\begin{array}{c}\text { Single } \\
\text { Coverage }\end{array}$ & $\begin{array}{c}\text { Family } \\
\text { Coverage }\end{array}$ & $\begin{array}{c}\text { Single } \\
\text { Coverage }\end{array}$ & $\begin{array}{c}\text { Family } \\
\text { Coverage }\end{array}$ \\
\hline (1) 2011-13 Change in Total Premium & $-\$ 970$ & $-\$ 2,061$ & $-\$ 662$ & $-\$ 1,366$ \\
\hline (2) 2011-13 Change in Employee Premium & $\$ 538$ & $\$ 1,025$ & $\$ 572$ & $\$ 1,067$ \\
\hline (3) 2011-13 Change in District Premium: (1) - (2) & $-\$ 1,507$ & $-\$ 3,086$ & $-\$ 1,234$ & $-\$ 2,433$ \\
\hline (4) 2007-2011 Trend in Total Premium & $\$ 312$ & $\$ 743$ & $\$ 276$ & $\$ 652$ \\
\hline (5) 2007-2011 Trend in Employee Premium & $\$ 20$ & $\$ 58$ & $\$ 14$ & $\$ 48$ \\
\hline (6) 2007-2011 Trend in District Premium: (4) - (5) & $\$ 293$ & $\$ 685$ & $\$ 262$ & $\$ 603$ \\
\hline TOTAL IMPACT OF ACT 10 ON DISTRICT PREMIUM: & & & & \\
\hline (7) 2011-13 CHANGE IN DISTRICT PREMIUM MINUS TREND: (3) - 2 x (6) & $-\$ 2,093$ & $-\$ 4,456$ & $-\$ 1,757$ & $-\$ 3,640$ \\
\hline (8) impact on total premium, relative to trend: (1) - $2 \times(4)$ & $-\$ 1,594$ & $-\$ 3,546$ & $-\$ 1,213$ & $-\$ 2,669$ \\
\hline (9) minus impact on employee premium, relative to trend: $-[(2)-2 \times(5)]$ & $-\$ 499$ & $-\$ 910$ & $-\$ 544$ & $-\$ 971$ \\
\hline (10) percent from total premium reduction: $\quad(8) /(7)$ & $76 \%$ & $80 \%$ & $69 \%$ & $73 \%$ \\
\hline (11) percent from higher employee premium: $(9) /(7)$ & $24 \%$ & $20 \%$ & $31 \%$ & $27 \%$ \\
\hline (12) PERCENT IMPACT OF ACT 10: (7)/projected 2013 district pre & $-23 \%$ & $-21 \%$ & $-20 \%$ & $-18 \%$ \\
\hline
\end{tabular}

Estimates tie to Figures 8 and 9 . Totals may not be exact due to rounding.

Sources: Wisconsin Association of School Boards, "Teacher Health Insurance Cost and Contribution Comparisons";

Wisconsin Department of Public Instruction for FTE weights; author's calculations. 


\section{Figure 1: Estimated Annual Insurance Cost to Employer, 2004-2015}

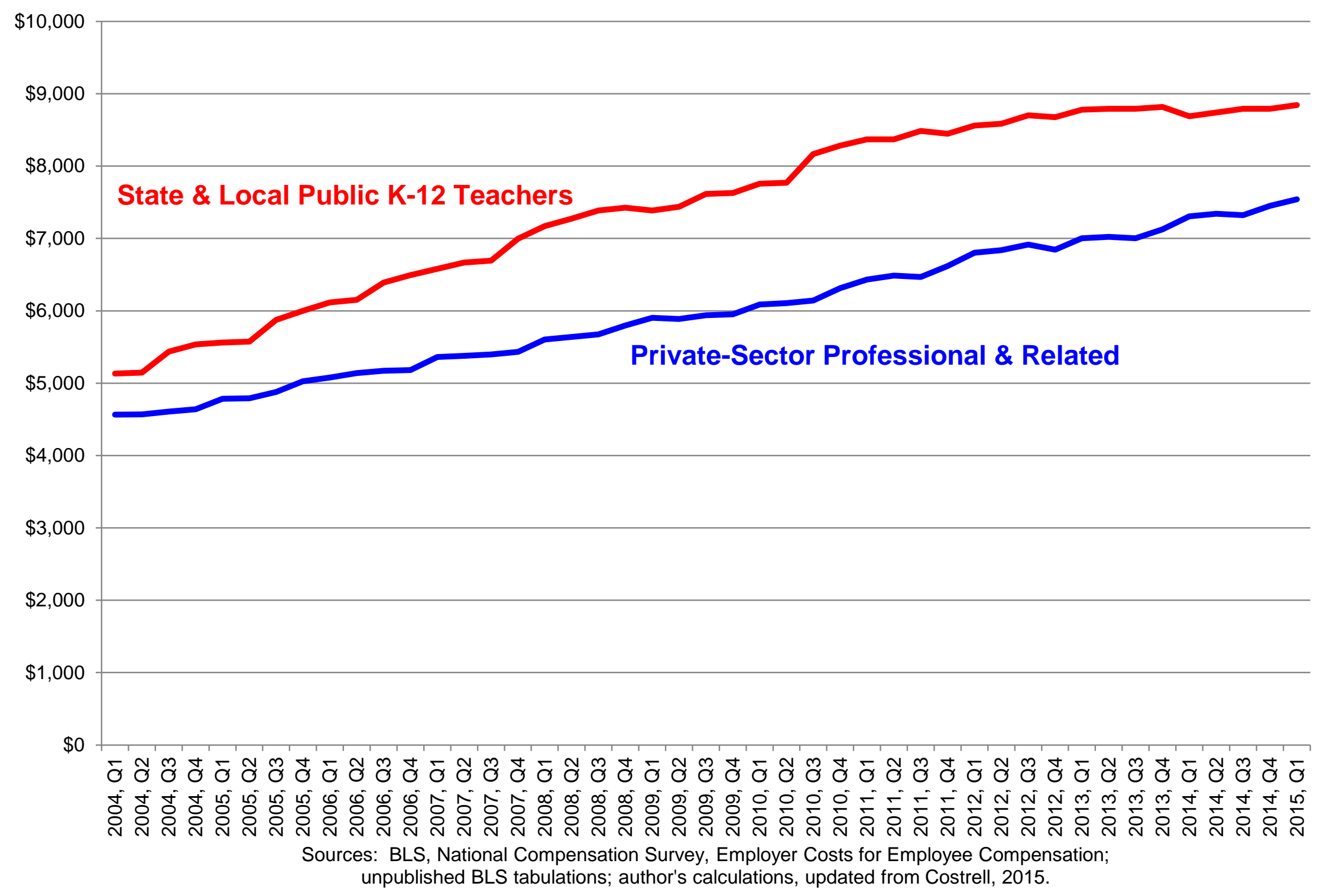




\section{Figure 2: Annual Employer Medical Care Premiums, 2008-2014}

Single and Family Coverage

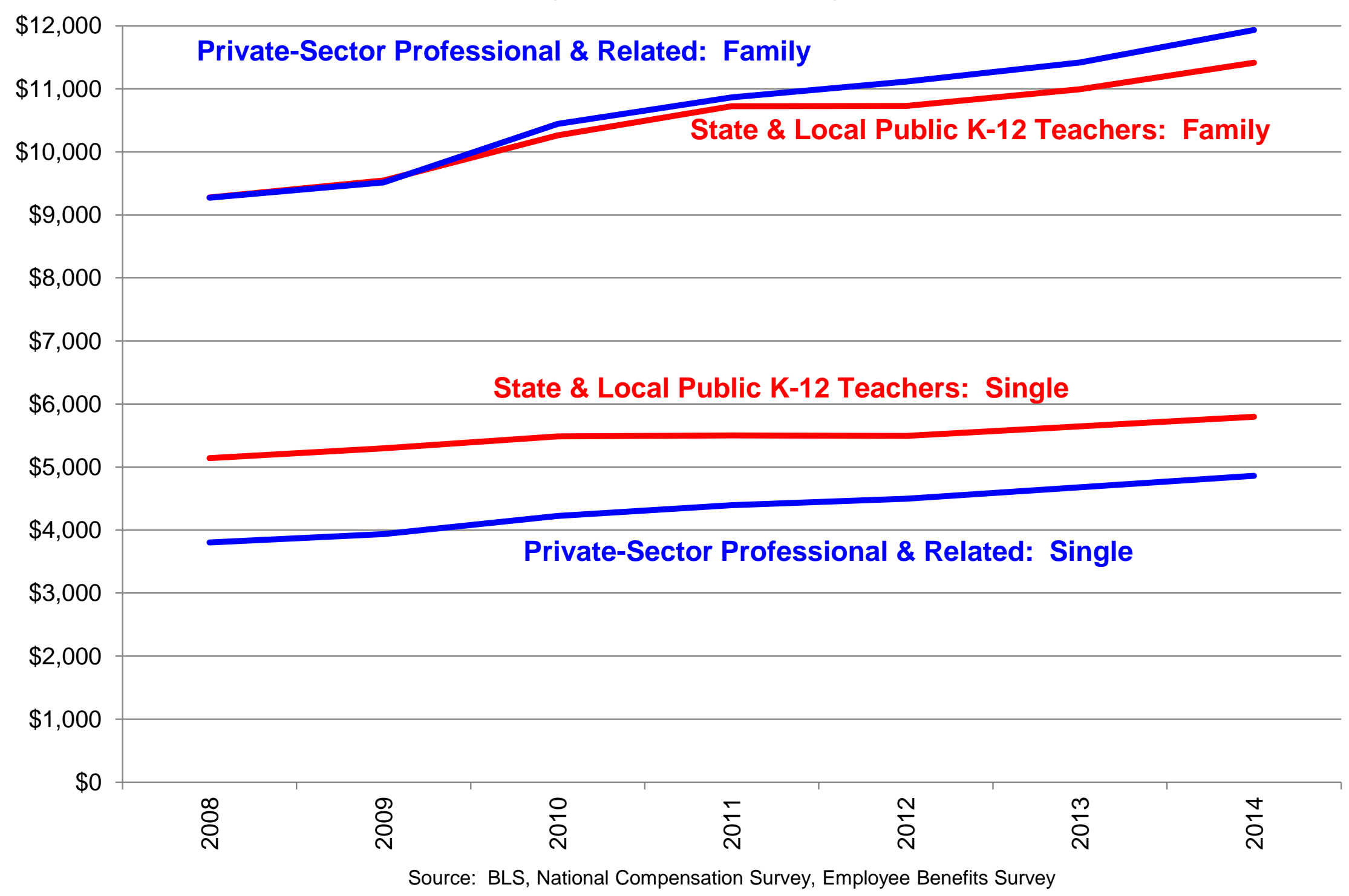


Figure 3: Employer, Employee, and Total Medical Premiums

K-12 Teachers and Private-Sector Professionals, March 2014

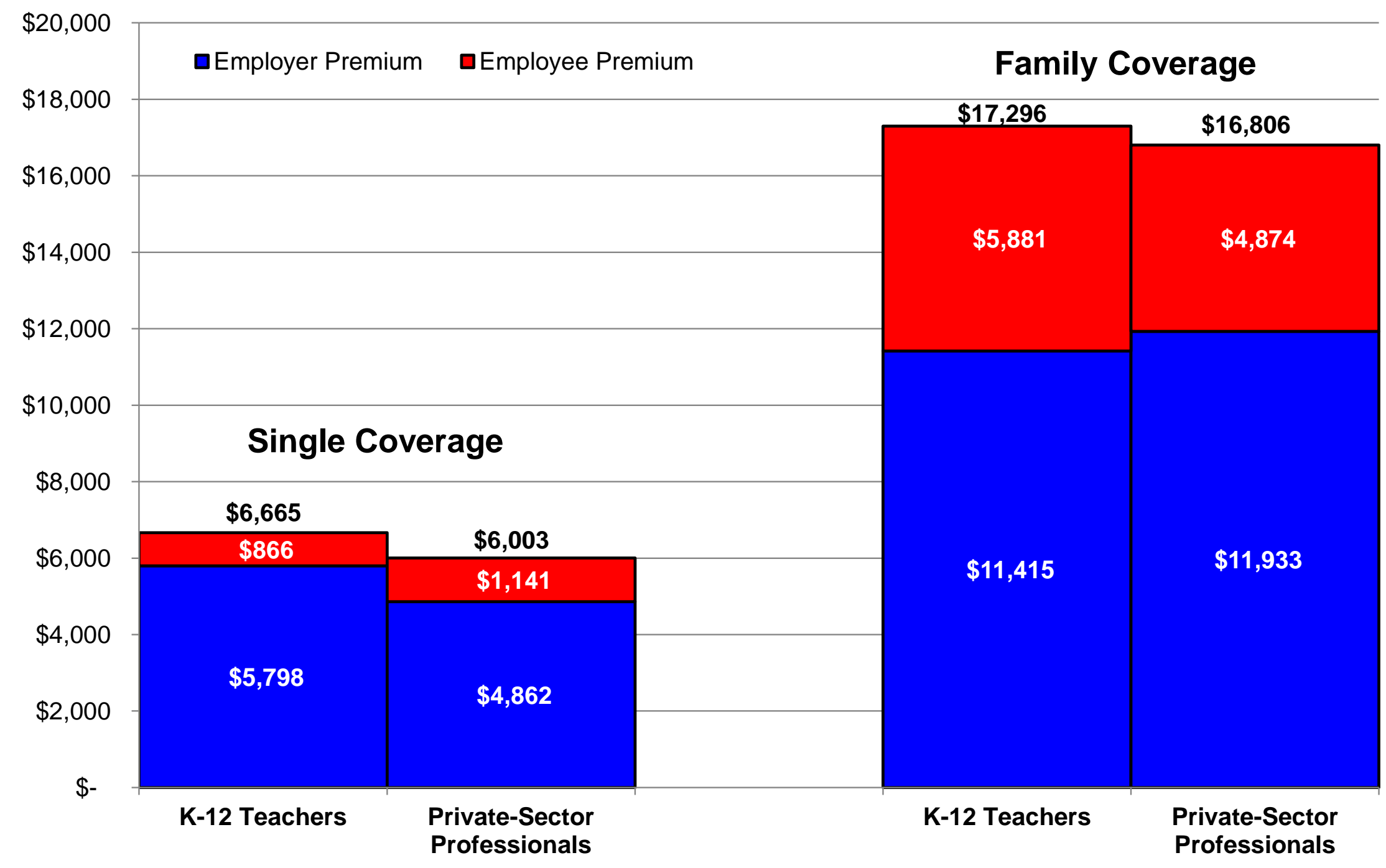

Sources: BLS National Compensation Survey, Employee Benefits Survey; author's calculations. 


\section{Figure 4: Medical Care Premiums, by Union Status}

State \& Local and Private Sector, March 2014

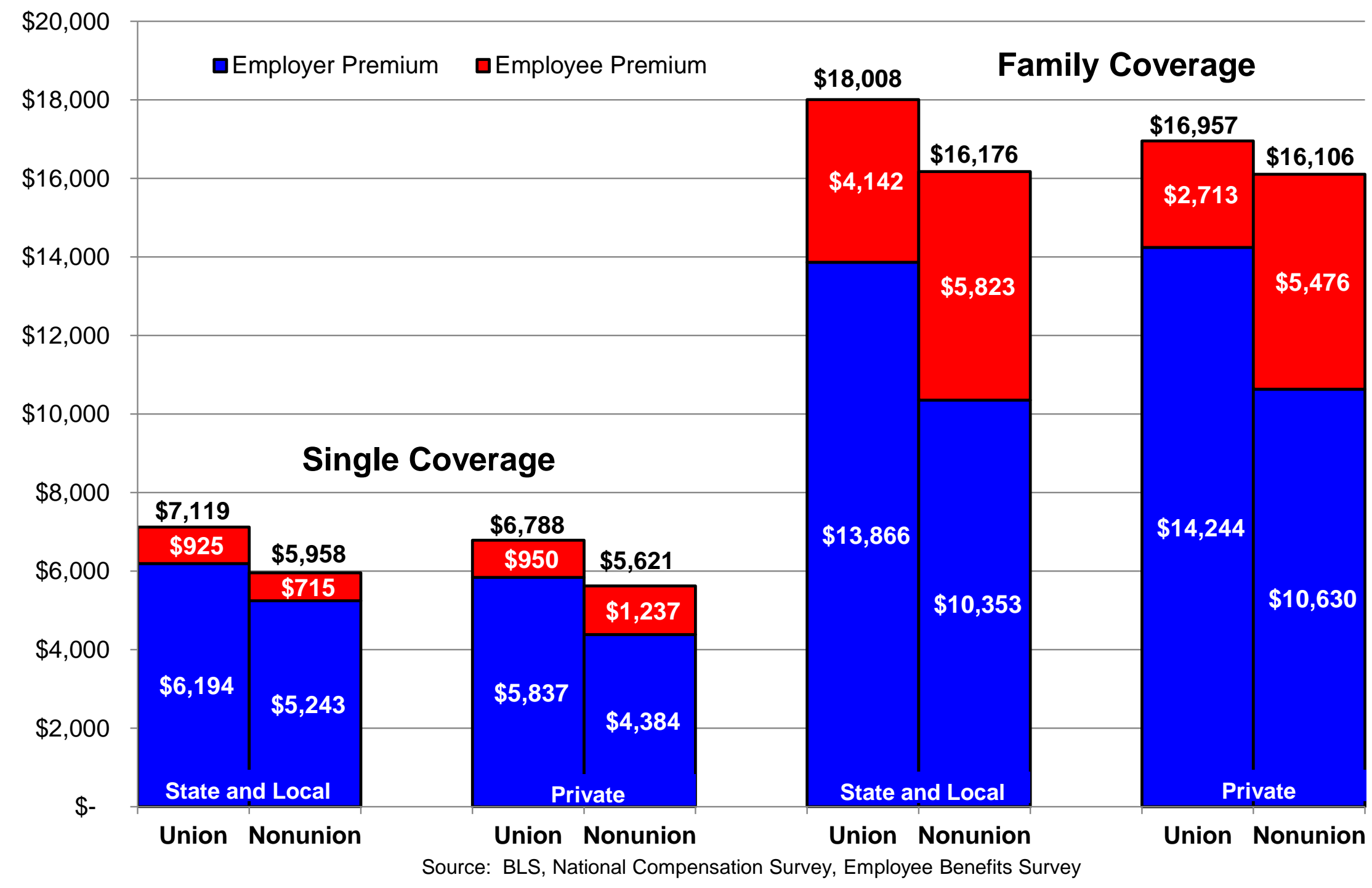




\section{Figure 5: Average District Medical Premium, Wisconsin, 2003-2013}

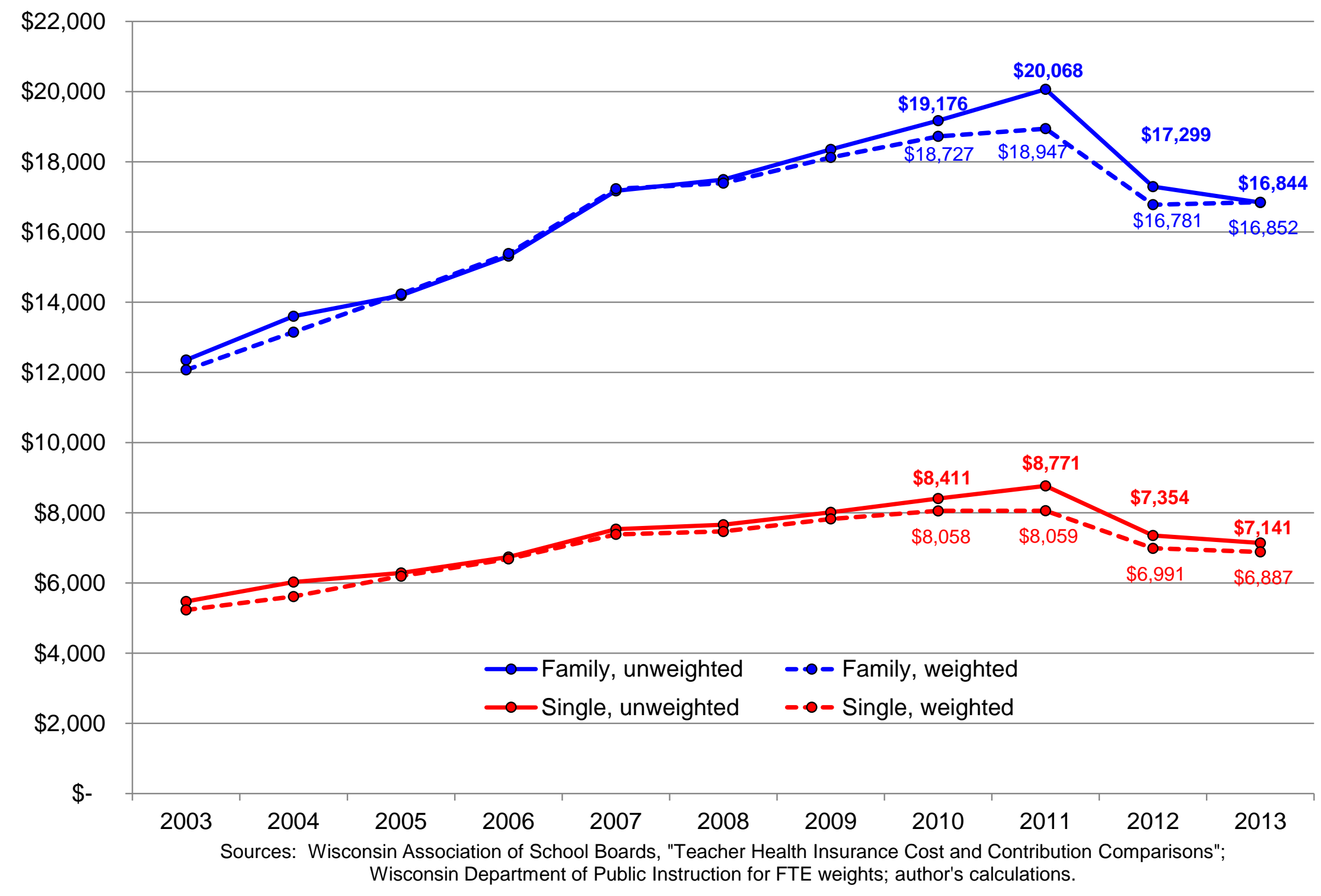


Figure 6: Chained District Medical Premiums, Wisconsin, 2003-2013

Note: 2010 base

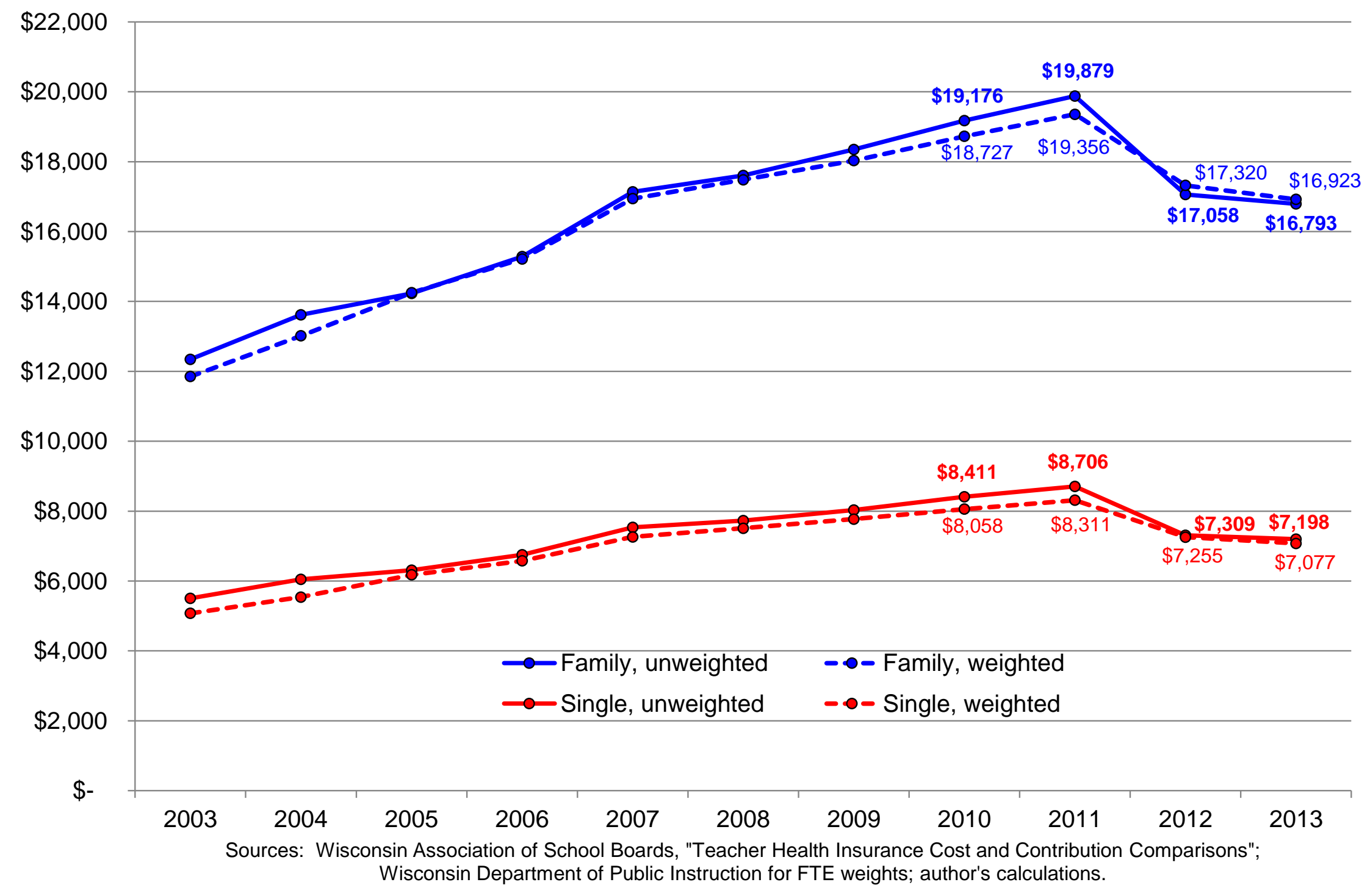


Figure 7: Teacher's Share for Medical Premiums, Wisconsin, 2003-2013

weighted chained estimates, 2010 base

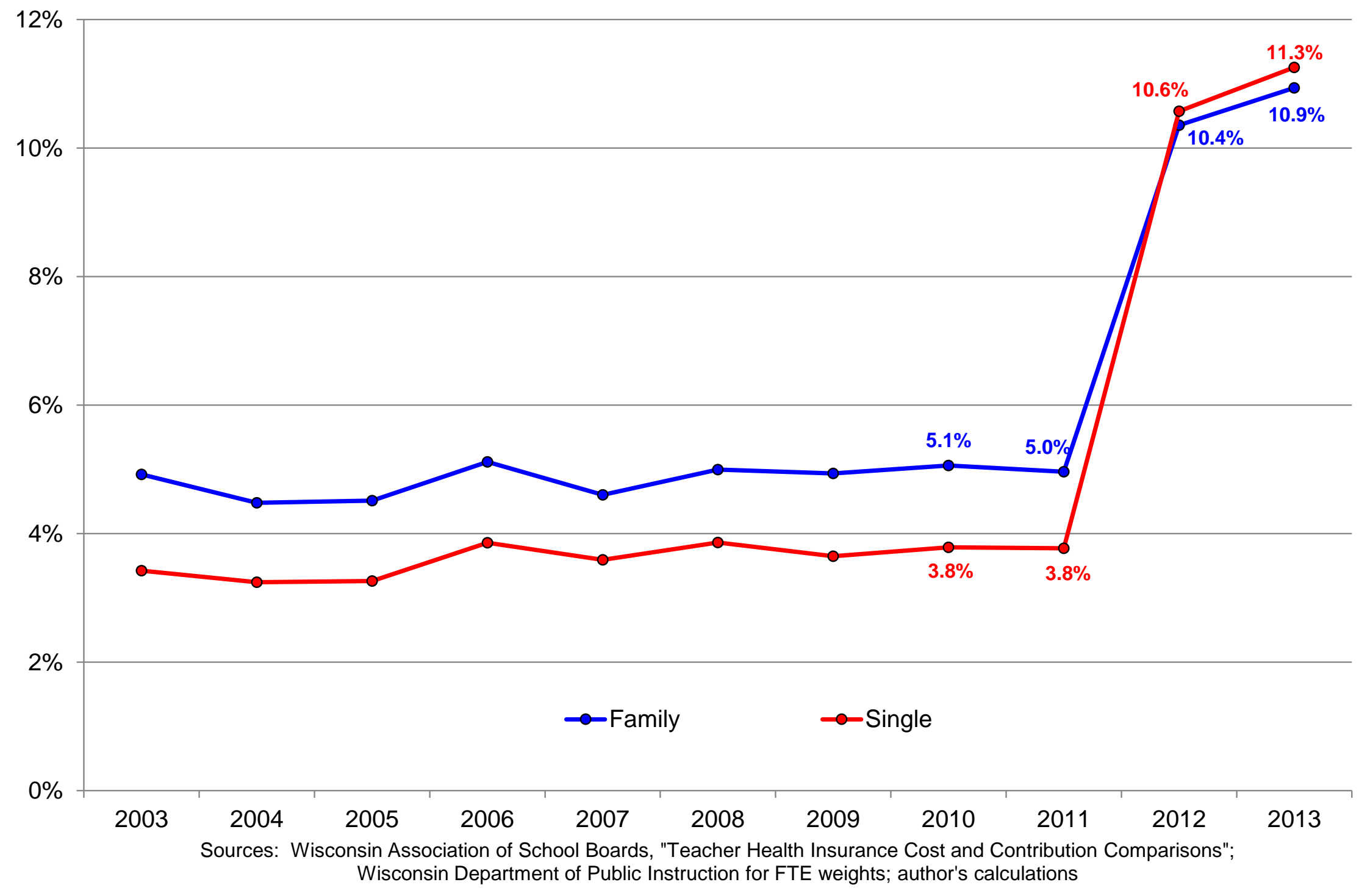


Figure 8: Total and District Premium, Wisconsin, Unweighted, 2003-2013

chained estimates, 2010 base

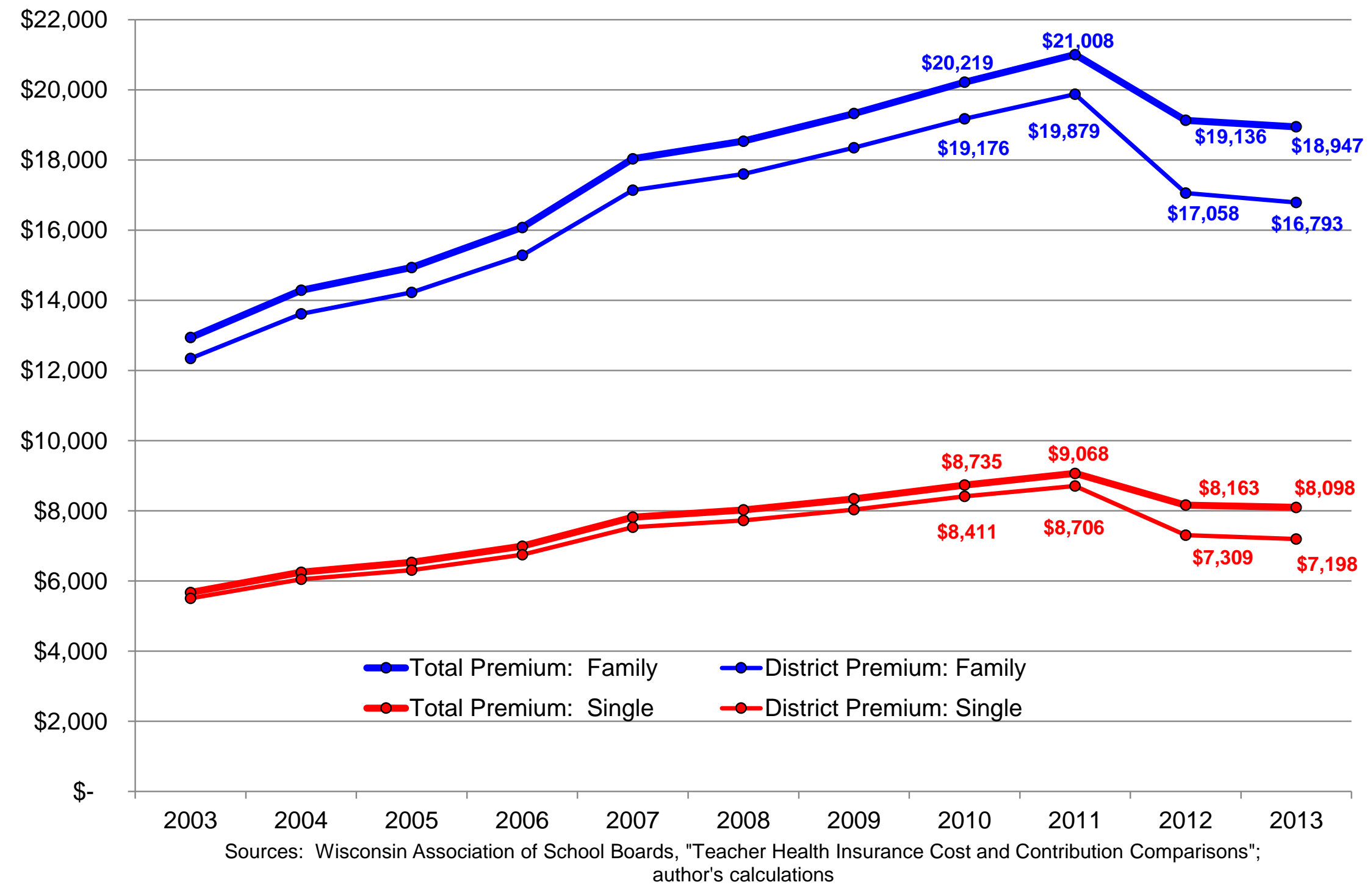


Figure 9: Total and District Premium, Wisconsin, Weighted, 2003-2013

chained estimates, 2010 base

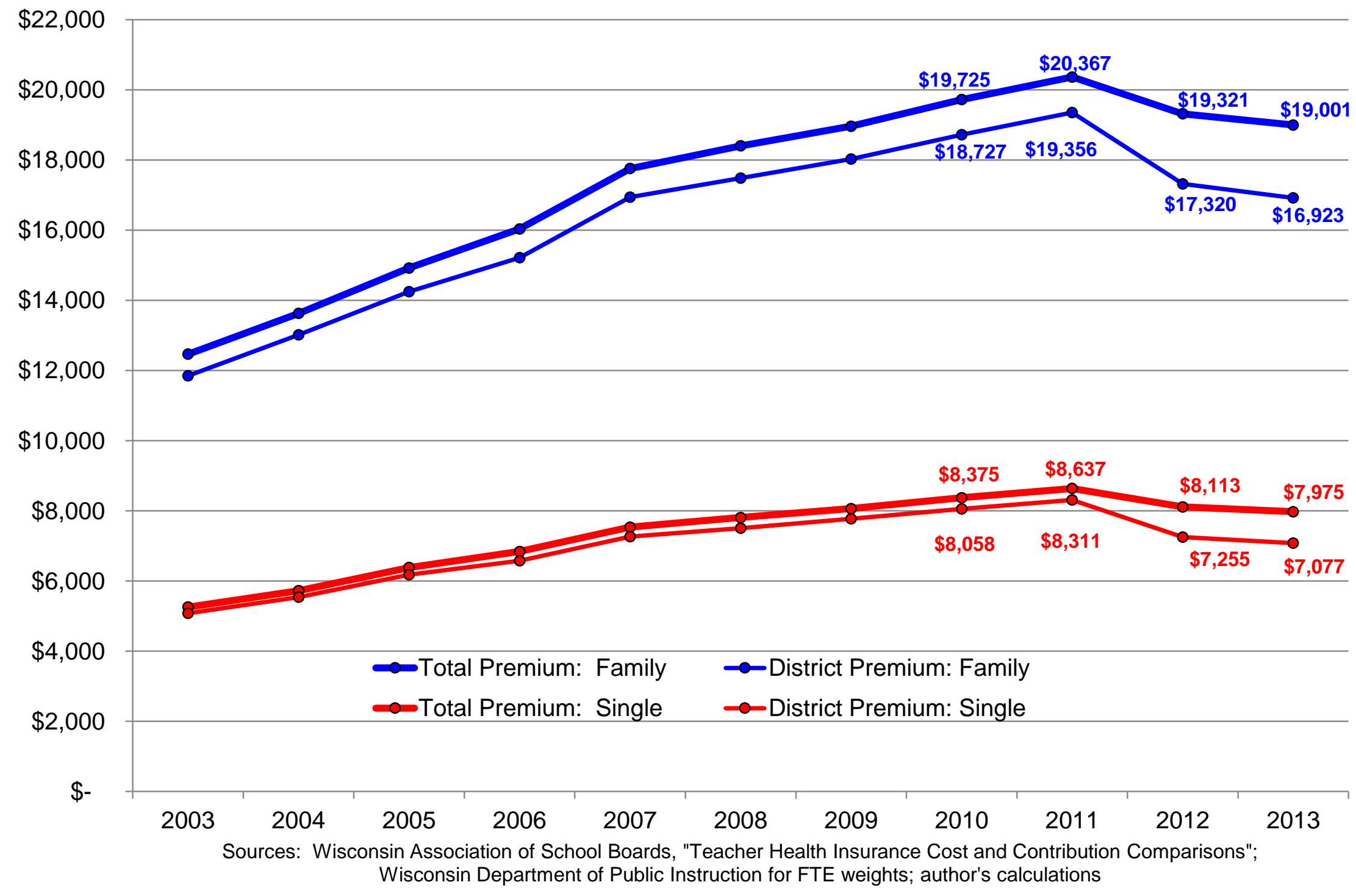


Figure 10: Fringe Benefit Costs for Teachers, Wisconsin, 1998-2013 (with percent of salary)

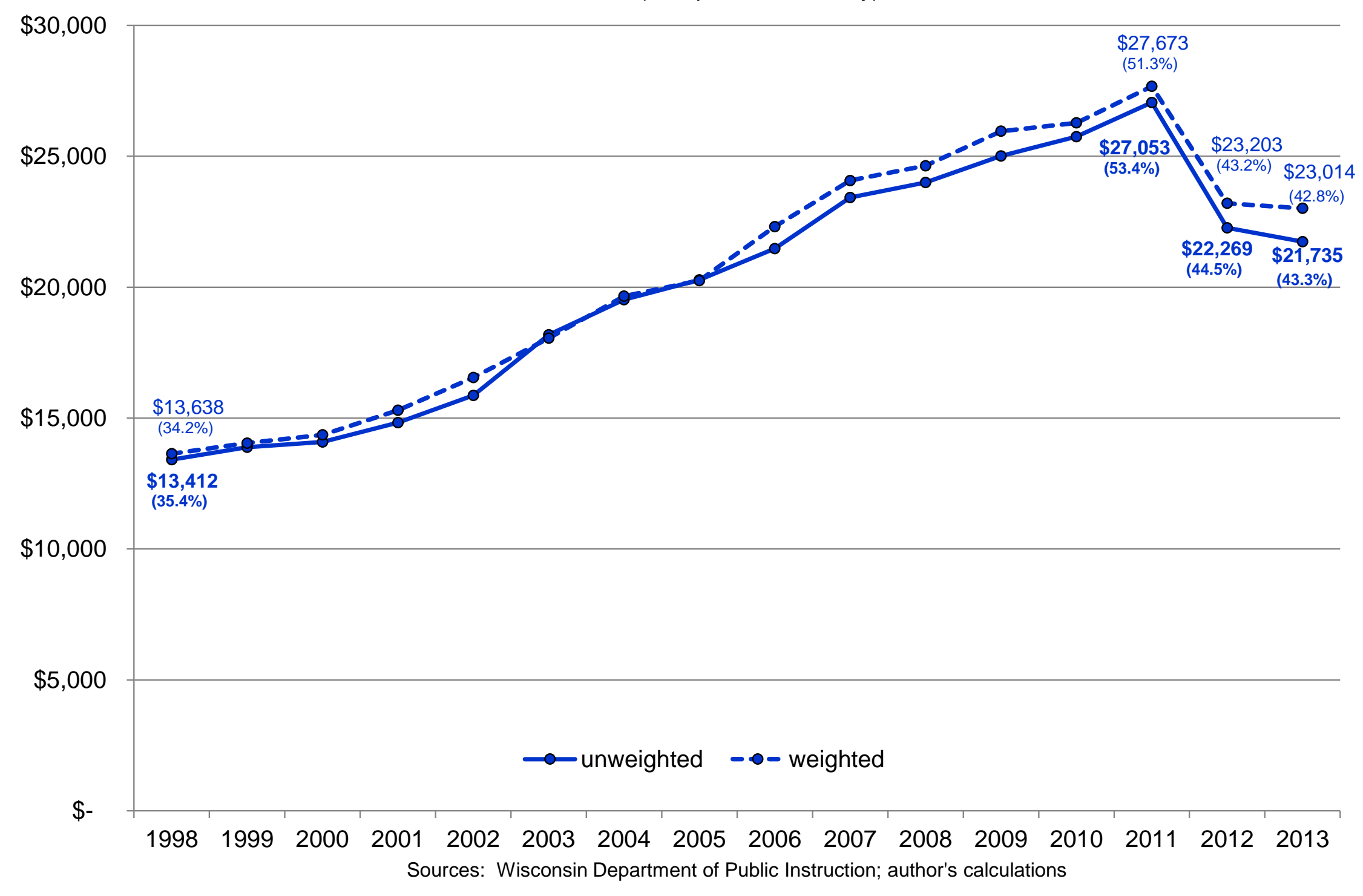

